\title{
Decoding the dynamics of poleward shifting climate zones using aqua-planet model simulations
}

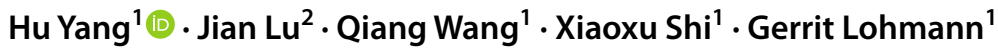

Received: 15 March 2021 / Accepted: 14 December 2021 / Published online: 5 January 2022

(c) The Author(s) 2022

\begin{abstract}
Growing evidence indicates that the atmospheric and oceanic circulation experiences a systematic poleward shift in a warming climate. However, the complexity of the climate system, including the coupling between the ocean and the atmosphere, natural climate variability and land-sea distribution, tends to obfuscate the causal mechanism underlying the circulation shift. Here, using an idealised coupled aqua-planet model, we explore the mechanism of the shifting circulation, by isolating the contributing factors from the direct $\mathrm{CO}_{2}$ forcing, the indirect ocean surface warming, and the wind-stress feedback from the ocean dynamics. We find that, in contrast to the direct $\mathrm{CO}_{2}$ forcing, ocean surface warming, in particular an enhanced subtropical ocean warming, plays an important role in driving the circulation shift. This enhanced subtropical ocean warming emerges from the background Ekman convergence of surface anomalous heat in the absence of the ocean dynamical change. It expands the tropical warm water zone, causes a poleward shift of the mid-latitude temperature gradient, hence forces a corresponding shift in the atmospheric circulation and the associated wind pattern. The shift in wind, in turn drives a shift in the ocean circulation. Our simulations, despite being idealised, capture the main features of the observed climate changes, for example, the enhanced subtropical ocean warming, poleward shift of the patterns of near-surface wind, sea level pressure, storm tracks, precipitation and large-scale ocean circulation, implying that increase in greenhouse gas concentrations not only raises the temperature, but can also systematically shift the climate zones poleward.
\end{abstract}

Keywords Tropical expansion · Poleward shift · Ocean circulation · Atmosphere circulation · Climate zones

\section{Introduction}

An increasing amount of evidence suggests that the atmospheric and oceanic circulation is shifting towards the poles under climate change (Thompson et al. 2000; Marshall 2003; Fu et al. 2006; Hu and Fu 2007; Lu et al. 2007; Seidel et al. 2008; Screen et al. 2018). For example, poleward migration of the patterns of storm tracks (Yin 2005), winds (Thompson et al. 2000; Chen et al. 2008), jet streams (Archer and Caldeira 2008), precipitation (Scheff and Frierson 2012), tropical cyclones (Kossin et al. 2014), atmospheric frontal activity (Rudeva and Simmonds 2015), cloud (Norris et al. 2016), atmospheric rivers (Ma et al. 2020) and large-scale

Hu Yang

hu.yang@awi.de

1 Alfred Wegener Institute, Helmholtz Centre for Polar and Marine Research, Bremerhaven, Germany

2 Atmospheric Sciences and Global Change Division, Pacific Northwest National Laboratory, Richland, WA, USA ocean circulation (Wu et al. 2012; Yang et al. 2016b, 2020a; Wu et al. 2021) have been identified based on various observations and climate simulations. These climate pattern shifts redistribute the natural resources, such as water, vegetation and the related ecosystems, thus having broad implications for our societies (Heffernan 2016). Understanding the underlying causes does not only help us to understand why it happens, but also serve to better predict and boost our confidence in the global warming induced climate changes.

In the past decades, numerous investigations have been carried out to decode the mechanisms (Staten et al. 2018; Shaw 2019). Early studies have been mainly focused on the atmospheric processes in driving the shift in the atmospheric circulation, concentrating on a specific topic named tropical expansion (Fu et al. 2006; Seidel et al. 2008; Chen et al. 2008). Climate model simulations can reproduce the tropical expansion by changing the atmospheric concentration of greenhouse gases (Lu et al. 2007), ozone (Thompson et al. 2011; Polvani et al. 2011), aerosols (Allen et al. 2012) or by introducing uniform sea surface temperature (SST) warming 
(Chen et al. 2013). Some of these simulations are even without involving changes in the ocean. However, observations imply that the spatial and temporal evolution of SST play a dominant role in driving the recent tropical expansion (Allen and Kovilakam 2017; Grise et al. 2019). And those SST variations were interpreted as a feature of fluctuations of the Pacific Decadal Oscillation, which is one of the internal climate variabilities. Therefore, growing number of studies suggest that the observed tropical expansion is more attributable to the natural climate variability than the anthropogenic climate change. More recently, following the finding of shifting large-scale ocean circulation, Yang et al. (2020a, 2020b) highlight that the entire atmospheric and oceanic circulation is moving towards the higher latitudes, which is not solely owing to natural climate variability. This is because that many of the observed climate trends, such as the patterns of sea level pressure (SLP), sea surface height (SSH) and nearsurface winds, well resemble the patterns obtained from the climate simulations forced by increasing greenhouse gases. Yang et al. (2020b) found that the meridional displacements of the atmospheric circulation are closely related to the displacement of midlatitude meridional temperature gradients (MTG). They proposed that an enhanced subtropical ocean warming (Fig. 1a) with an oceanic origin contributes to a poleward advancing of the mid-latitude MTG, and drives the circulation shift.

Due to the coupled nature between the atmosphere and ocean, it is challenging to tease out the causality for the shift
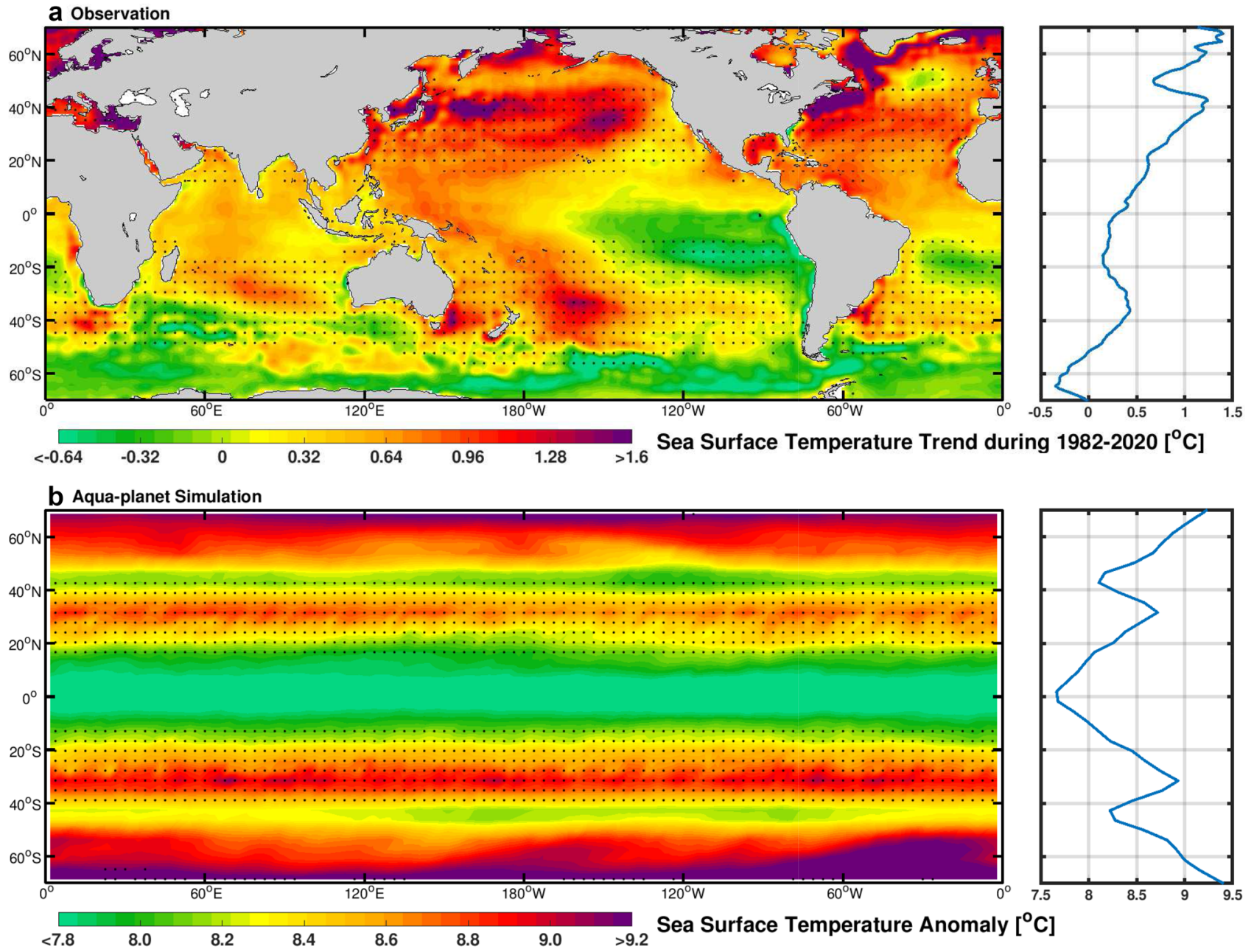

Fig. 1 a Observational sea surface temperature (SST) trend during the satellite era (1982-2020). Relatively stronger ocean surface warming is found over almost all the western basins of the subtropical oceans, likely due to the background Ekman convergence of surface water. Result based on the NOAA Optimum Interpolation (OI) SST V2 dataset. The stippled area shows the subtropical convergence zone based on the field of near-surface wind stress curl from the ERA5 reanalysis (1982-2020). The right panel presents the zonal mean values of the SST trend. b Similar to Fig. 1a, but for SST anomaly in the last 40 years of the aqua-planet $\mathrm{C} 1$ global warming experiment with respect to the last 140 years of the $\mathrm{C} 0$ control experiment. Unlike the zonally symmetric enhanced subtropical ocean warming in the aqua-planet simulation, the observational enhanced subtropical ocean warming concentrates more towards the western ocean basins, where the centers of the subtropical gyres locate 
of the large-scale circulation. Several questions still remain to be answered. For example, does the shift in the atmosphere circulation drive the shift in the ocean circulation, or vice versa? Could the forced climate change generate an enhanced subtropical ocean warming, so that it can serve as an independent forcing mechanism for the shift of the atmospheric circulation? To provide insight on these questions, we consider a simplified ocean-atmosphere coupled aqua-planet framework, without asymmetric land-sea distribution, sea ice and deep ocean circulation. Within the framework, we manipulate the configurations of the forcing so as to isolate the impacts of the direct radiative forcing from increasing greenhouse gases (in our experiments, greenhouse gases refer to only $\mathrm{CO}_{2}$ ) and the indirect one through SST warming. Additionally, by specifying the wind stress seen by the ocean, we further isolate the circulation response without the wind-stress feedback from the ocean adjustment. This idealised approach allows us to partition the full circulation response into different mechanisms in a quantitative manner, so as to pinpoint the leading cause for the circulation shifts in both ocean and atmosphere.

\section{Experiments and methodology}

\subsection{Experiment design}

We used a coupled aqua-planet setup of the Alfred Wegener Institute Earth System Model (AWI-ESM, Sidorenko et al. (2015); Rackow et al. (2018); Sidorenko et al. (2019)), in which the Earth is covered by ocean, except the region higher than $85^{\circ}$ latitude (Fig. S1). The two islands at both poles are needed to avoid pole singularity in the ocean model. The atmospheric component is ECHAM6 (Stevens et al. 2013) with a horizontal resolution of $3.75^{\circ}$ (T31 grid). The coupled ocean component is FESOM1.4 (Wang et al. 2014) with a resolution of approximately $2.5^{\circ}$. The atmosphere has 47 vertical layers, and the ocean has 7 layers and a uniform shallow water depth of 100 meters. The shallow ocean setup well mimics the main structure of the winddriven ocean circulation (Fig. 2 and S2). The configuration of Earth's orbital parameters and the related distribution of solar radiation is kept the same as the real-world configuration, including both diurnal and seasonal cycles. This allows the model to capture the high-frequency variability of the baroclinic systems, which are important for the meridional transports of heat, moisture and momentum (Rudeva et al. 2019; Lin et al. 2020). The ocean-atmosphere coupling time step is set to be one hour.

We perform two simulations using the fully coupled AWI-ESM, i.e., a control experiment (i.e., C0) and a global warming experiment (i.e., C1). The control simulation (C0) is integrated for 640 years with the pre-industrial $\mathrm{CO}_{2}$ configuration (i.e., $284 \mathrm{ppmv}$ ). The global warming simulation $(\mathrm{C} 1)$ is initialised from the 500th model year of the $\mathrm{C} 0$ experiment and integrated for 140 years by increasing the concentration of $\mathrm{CO}_{2}$ linearly from $284 \mathrm{ppmv}$ to $1284 \mathrm{ppmv}$ within 100 years. Afterwards, the $\mathrm{CO}_{2}$ level is kept constant at the value of 1284 ppmv (Fig. 3). The hourly coupling fields of SST and near-surface wind stress from the C0 and $\mathrm{C} 1$ experiments are saved and used later in the partially coupled simulations.

To quantify the contribution of $\mathrm{CO}_{2}$ and SST in driving the atmospheric circulation shift, we perform two partially coupled experiments, i.e., C1T0 and C0T1. In the C1T0 experiment, we increase the $\mathrm{CO}_{2}$ as in the $\mathrm{C} 1$ global warming experiment, but replace the hourly coupling SST field in the atmosphere model with that from the control experiment (i.e., C0). Distinct from the C1T0 experiment, the C0T1 experiment is integrated with the constant pre-industrial $\mathrm{CO}_{2}$ level, but the SST is replaced with that from the global warming experiment (i.e., C1).

To explore the dynamics of the systematic shift in circulation, we carry out another three partially coupled simulations, i.e., C1W0, C0W1 and C0W0. In the C1W0 experiment, we increase the $\mathrm{CO}_{2}$ as in the $\mathrm{C} 1$ global warming experiment, but the hourly coupling near-surface wind stress into the ocean model is replaced with that from the $\mathrm{C} 0$ control experiment. In contrast, the $\mathrm{C} 0 \mathrm{~W} 1$ experiment is integrated under the constant pre-industrial $\mathrm{CO}_{2}$ level, but with the winds replaced with that from the $\mathrm{C} 1$ global warming experiment, which contains a signal of poleward shift. As replacing wind stress itself could introduce a climate anomaly, we perform the third experiment, i.e., COW0, as a reference control run for the partially coupled simulations. It runs under the constant pre-industrial $\mathrm{CO}_{2}$ configuration, with the wind taken from the $\mathrm{C} 0$ experiment. The 499th model year of the $\mathrm{C} 0$ experiment is used to initialise all these partially coupled experiments. Note that if the 500th model year of $\mathrm{C} 0$ experiment is used for initialisation, the COW0 result will be identical to that of the $\mathrm{C} 0$ experiment.

The last 40 years of the sensitivity experiments (i.e., $\mathrm{C} 1$, C1T0, C0T1, C0W1, C1W0) are used to compare with the 140 years of the control experiments (i.e., $\mathrm{C} 0$ and $\mathrm{C} 0 \mathrm{~W} 0$ ). Table 1 summarises the above mentioned experiments.

\subsection{Methodology}

We use two metrics to quantify the meridional locations of the atmospheric and oceanic circulation. The location of the atmospheric circulation is obtained as the mean positions of the subtropical high and subpolar low SLP systems over both hemispheres. This is primarily based on the fact that the subtropical high SLP systems locate at the boundary between the Hadley cell and the Ferrel cell, and the subpolar low SLP systems mark the confluence region of the Ferrel cell and the 
Table 1 List of aqua-planet simulations in this study

\begin{tabular}{|c|c|c|c|}
\hline $\begin{array}{l}\text { Experiment } \\
\text { name }\end{array}$ & Initial condition & $\begin{array}{l}\text { Simulation } \\
\text { years }\end{array}$ & Brief description \\
\hline $\mathrm{C} 0$ & Prescribed zonally constant climate fields & 640 & Pre-industrial control run, constant $\mathrm{CO}_{2}$ level at $284 \mathrm{ppmv}$. \\
\hline $\mathrm{C} 1$. & 500th year of the $\mathrm{C} 0$ experiment & 140 & $\begin{array}{l}\text { Global warming run, linearly increase the } \mathrm{CO}_{2} \text { from } 284 \mathrm{ppmv} \text { to } \\
1284 \text { ppmv within } 100 \text { years, keep it constant at } 1284 \text { ppmv level } \\
\text { afterwards }\end{array}$ \\
\hline C1T0 & 500th year of the $\mathrm{C} 0$ experiment & 140 & Increase $\mathrm{CO}_{2}$ as in $\mathrm{C} 1$, but replace the coupling SST from $\mathrm{C} 0$ \\
\hline C0T1 & 500th year of the $\mathrm{C} 0$ experiment & 140 & Keep $\mathrm{CO}_{2}$ constant as in $\mathrm{C} 0$, but replace the coupling SST from $\mathrm{C} 1$ \\
\hline COW0 & 499th year of the $\mathrm{C} 0$ experiment & 140 & $\begin{array}{l}\text { Partially coupled control run, keep } \mathrm{CO}_{2} \text { constant as in } \mathrm{C} 0 \text {, but replace } \\
\text { the coupling winds from } \mathrm{C} 0\end{array}$ \\
\hline C0W1 & 499th year of the $\mathrm{C} 0$ experiment & 140 & Keep $\mathrm{CO}_{2}$ constant as in $\mathrm{C} 0$, but replace the coupling winds from $\mathrm{C} 1$ \\
\hline C1W0 & 499th year of the $\mathrm{C} 0$ experiment & 140 & Increase $\mathrm{CO}_{2}$ as in $\mathrm{C} 1$, but replace the coupling winds from $\mathrm{C} 0$ \\
\hline
\end{tabular}

Fig. 2 Climatological patterns of the atmospheric and oceanic circulation in the aqua-planet $\mathrm{C} 0$ control experiment. a Stream function of the atmospheric overturning circulation. Positive values represent clockwise flow, and negative values stand for anticlockwise flow. b Zonal mean sea level pressure (SLP). The subtropical high SLPs are associated with sinking branches of the Hadley cell and the Ferrel cell, while the subpolar low SLPs are associated with the rising branches of the Ferrel cell and the Polar cell. c Zonal mean sea surface height (SSH). The subtropical high SSHs represent the centers of the real-world subtropical gyres, while the subpolar low SSHs denote the positions of the real-world subpolar gyres. d Stream function of the overturning circulation in the ocean. Positive values represent clockwise flow, and negative values stand for anticlockwise flow

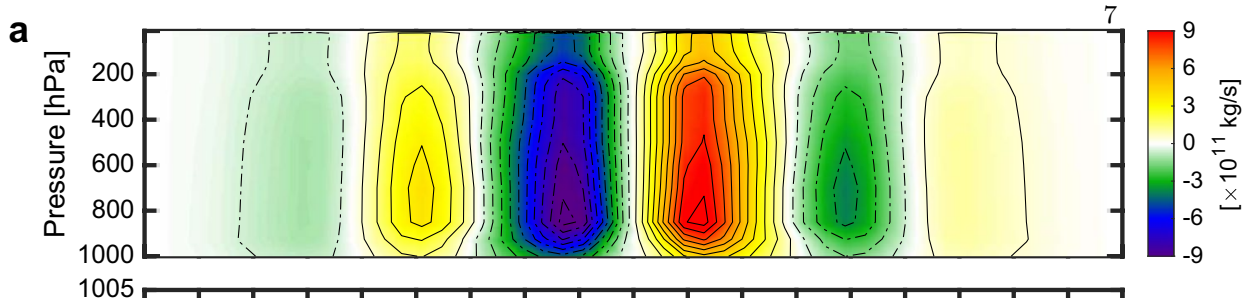

b

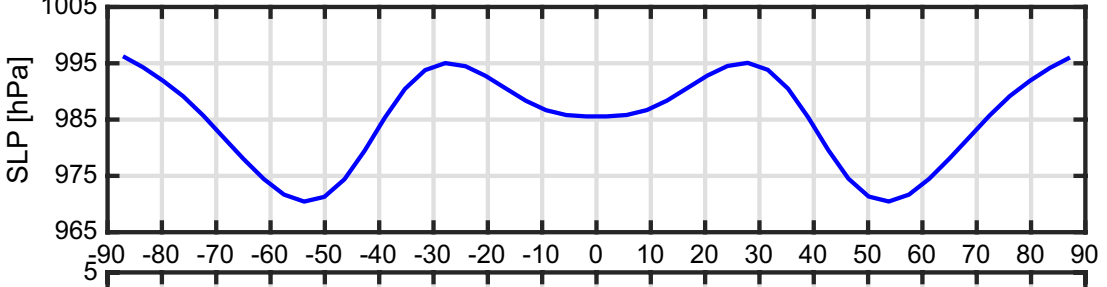

C

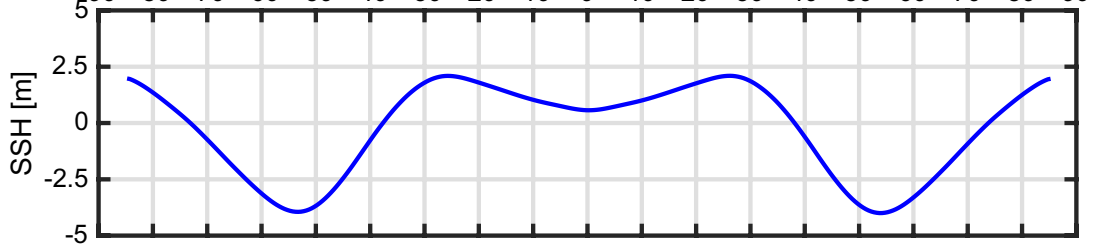

d

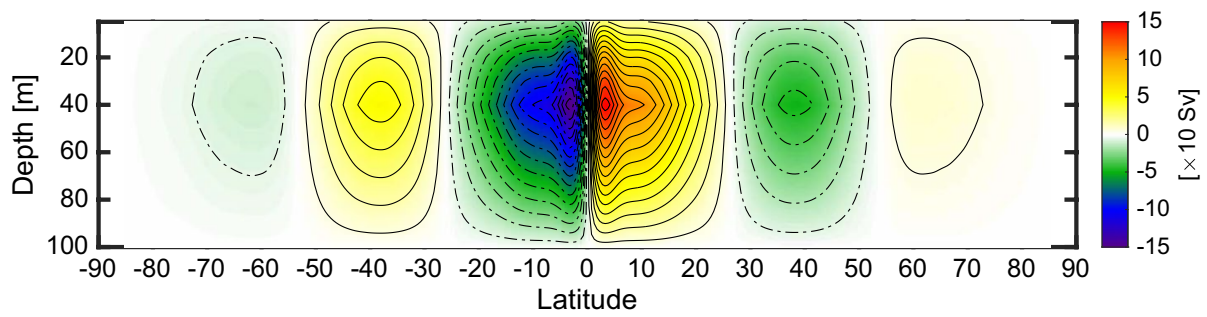

Polar cell (Fig. 2). Here, the position of the subtropical high (subpolar low) SLP is defined as the latitude where the zonal mean SLP reaches the peak high (low) value.

Similarly, we track the location of the ocean circulation by calculating the mean meridional positions of the subtropical high and subpolar low SSH, because the centers of the subtropical ocean gyres have relative high regional $\mathrm{SSH}$, and the centers of the subpolar gyres are featured by relatively low regional SSH (Yang et al. 2020a). Here, the position of the subtropical high (or subpolar low) SSH is estimated as the latitude where the zonal mean SSH field peaks.

As our aqua-planet modelling framework is statistically zonally symmetric, our analysis focuses only on the zonal mean aspect of the response. To quantify the shifting circulation with better spatial resolution, we interpolate the original zonal mean data onto a $0.01^{\circ}$ resolution grid using spline interpolation before our analysis. Finally, it should be 


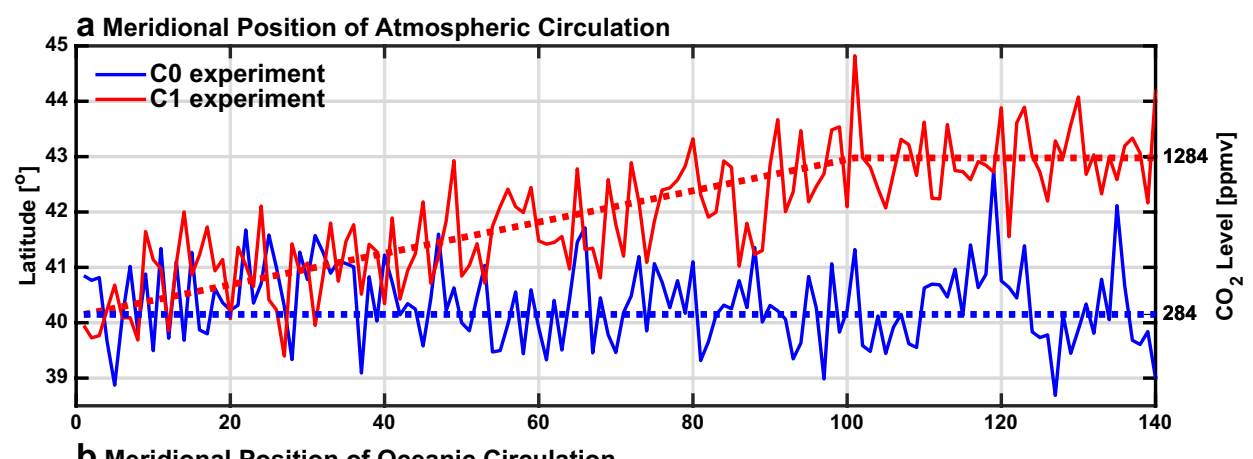

b Meridional Position of Oceanic Circulation

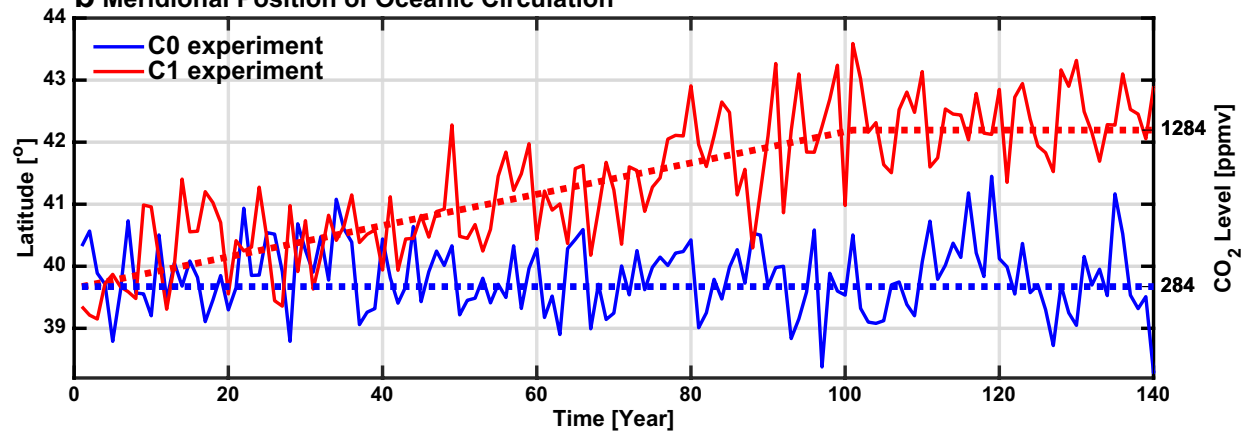

Fig. 3 Meridional position of $\mathbf{a}$ atmospheric circulation and $\mathbf{b}$ oceanic circulation in the aqua-planet control ( $\mathrm{C} 0$, blue lines) and global warming $(\mathrm{C} 1$, red lines) experiments. The position of the atmospheric circulation is calculated as the mean positions of the subtropical high and subpolar low SLP systems over both hemispheres. And the position of the oceanic circulation is obtained as the mean meridional positions of the subtropical high and subpolar low SSHs (detailed

noted that our analysis is based on the annual mean result and the seasonality will not be discussed in this paper.

\subsection{Observational data}

Satellite-derived observational SST [from the NOAA OISST dataset (https://www.esrl.noaa.gov/psd/)] and SSH (from the AVISO altimetry (http://www.aviso.altimetry.fr/duacs/)) are used to validate our results from the idealised aqua-planet simulations. Besides, the atmospheric reanalysis dataset ERA5 (Hersbach et al. 2020) and the ocean reanalysis dataset SODA2.2.0 (Carton and Giese 2008) are used as well to illustrate the structure of the atmospheric and oceanic circulation in the real world (Figs. S2 and S3).

\section{Results}

\subsection{Poleward shift of atmospheric and oceanic circulation in a warming climate}

Figures 2, 3 and 4 present the results of the fully coupled aqua-planet model simulations. As shown, the control experiment $\left(\mathrm{C} 0\right.$, blue lines) simulates a SST profile from $33^{\circ} \mathrm{C}$ definition can be found in Sect. 2.2). The solid lines represent the meridional position, and the dashed lines are the concentration of $\mathrm{CO}_{2}$. The displacement of the atmospheric circulation is strongly coupled with that of the oceanic circulation. The correlation coefficients between them reach 0.82 and 0.95 in the $\mathrm{C} 0$ and $\mathrm{C} 1$ experiments, respectively

near the equator to $5{ }^{\circ} \mathrm{C}$ near the poles. There are easterly near-surface winds at lower latitudes and westerly winds around the mid-latitudes. The precipitation minus evaporation (P-E) pattern illustrates large precipitation at the central tropics (i.e., the Inter Tropical Convergence Zone), and relatively dry subtropics and wet mid-latitudes. The SLP profile shows subtropical high and subpolar low pressure systems, corresponding to the sinking branch of the Hadley cell and rising branch of the Ferrel cell, respectively. Regarding the ocean circulation, relatively high/low SSHs are found near the subtropical/subpolar regions, representing the meridional centers of the subtropical/subpolar ocean gyres in reality. In general, these features generated by our aqua-planet simulation resemble the typical circulation structures shown in the observations (Fig. S2 and S3). It is worth noting that in our aqua-planet world, there is no polar sea ice due to low surface albedo and a relatively warm ocean near the poles. Previous aqua-planet model simulations also show a similar feature (Smith et al. 2006), likely owing to strong heat exchange between the low and high latitudes maintained by strong meridional overturning circulation in both ocean and atmosphere (see the comparison between Figs. 2 and S2). Owing to the high surface temperature around both poles and overall high effective heat capacity due to more ocean 

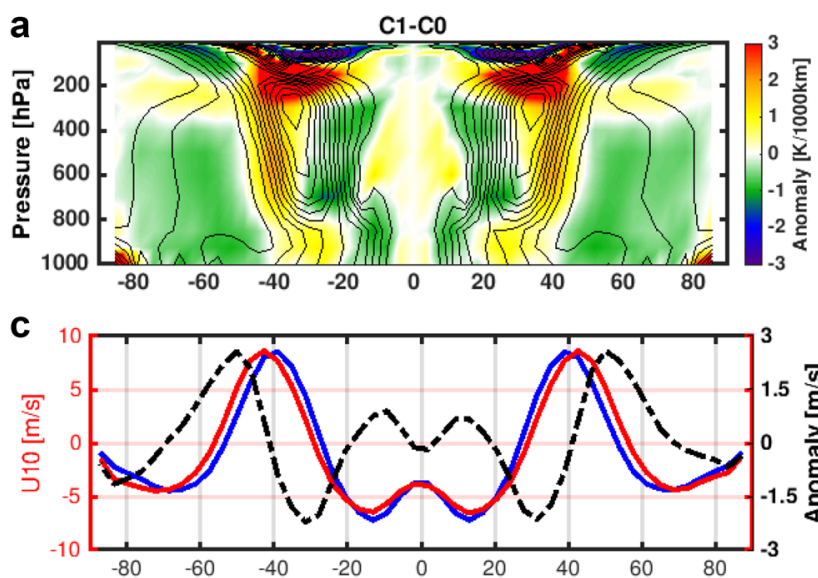

e

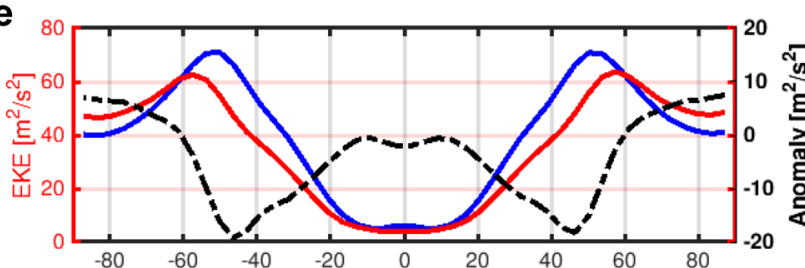

g

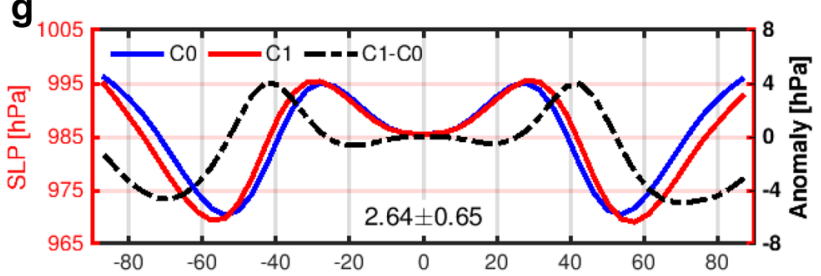

Fig. 4 Comparison between experiments of global warming (C1) and pre-industrial $(\mathrm{C} 0)$ showing a poleward shift of the atmospheric and oceanic circulation under warmer climate. a Meridional temperature gradient (MTG) anomaly (shading) in the $\mathrm{C} 1$ experiment with respect to the $\mathrm{C} 0$ control experiment. The contour lines provide the climatological pattern of the MTG in the $\mathrm{C} 0$ experiment. Zonal mean $\mathbf{b}$ sea surface temperature (SST), c zonal component of 10-m near-surface wind (U10), d ocean surface turbulent heat flux (THF, i.e., sensible + latent heat fluxes, positive-upward), e $850 \mathrm{hPa}$ eddy kinetic energy (EKE) as indication of storm track, $\mathbf{f}$ precipitation minus evaporation (P-E), $\mathbf{g}$ sea level pressure (SLP), h sea surface height (SSH). The blue lines show the value of the control experiment $(\mathrm{C} 0)$, the red

coverage than the real world (Lohmann 2020), the aquaplanet global mean surface temperature (i.e., $21.3^{\circ} \mathrm{C}$ ) is also higher than that in observations. Since there is no permanent zonal temperature gradient, our aqua-planet world has no fluctuations of El Nino-Southern Oscillation or Pacific Decadal Oscillation.

Comparing with the control run (C0), the global warming experiment $(\mathrm{C} 1)$ shows a weak polar amplification, despite the lack of sea ice-albedo feedback (Figs. 1b, 4b). Besides, an enhanced ocean warming is identified around the subtropical regions. Such pattern resembles the satellite observed SST trend as shown in Fig. 1a. We notice that the b

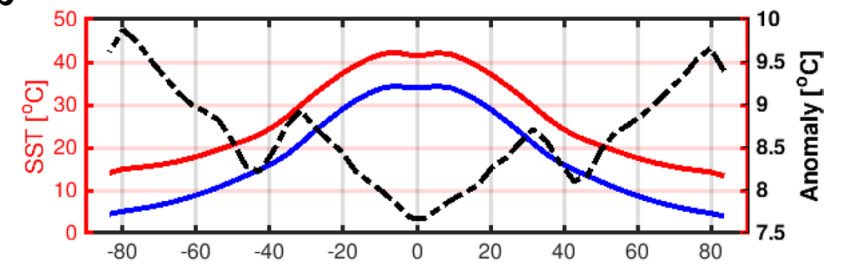

d

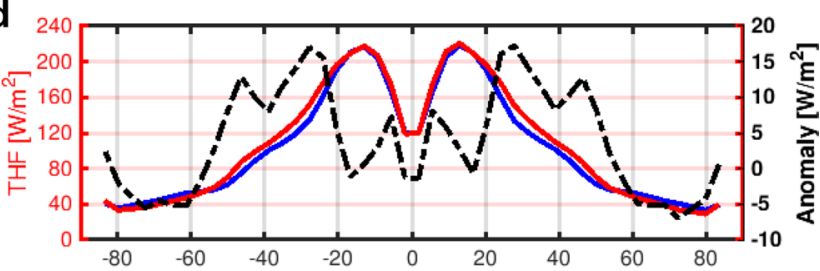

f

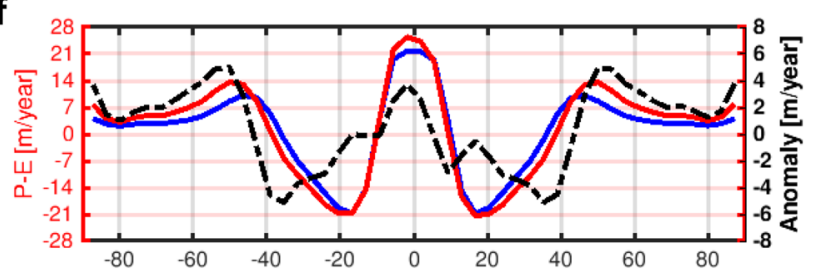

h

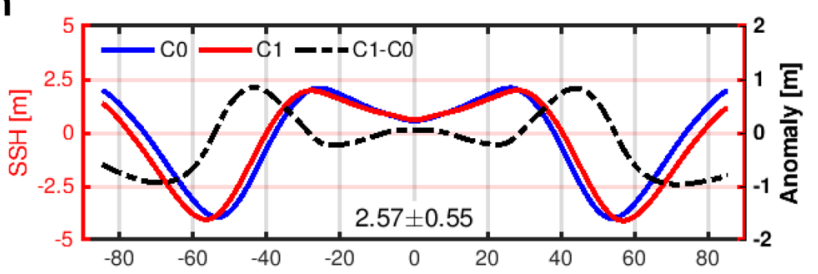

lines show the values from the global warming experiment $(\mathrm{C} 1)$, the dashed black lines are the difference between the global warming and the control experiments $(\mathrm{C} 1-\mathrm{C} 0)$. The texts in the last two sub-panels provide the magnitudes of the poleward shift in the atmospheric and oceanic circulation, respectively. The error bars represent the standard deviation of the natural variability of the meridional displacement of the atmospheric and oceanic circulation, respectively. These values are calculated based on the SLP and SSH fields, according to the definition introduced in Sect. 2.2. All results are based on the last 40 years of the global warming experiment $(\mathrm{C} 1)$ and 140 years of the control experiment $(\mathrm{C} 0)$

simulated SST anomalies are not hemisphere-symmetric. This is likely due to the asymmetric insolation caused by the Earth's elliptical orbit (Earth's perihelion occurs during the southern hemisphere summer). The enhanced subtropical ocean warming induces an anomalous upward ocean surface turbulent heat fluxes (i.e., sensible + latent heat fluxes, the main form of the ocean-atmosphere heat exchange (Yang et al. 2016a)) from the ocean to the atmosphere (Fig. 4d). Such anomalous subtropical heat flux has also been identified in the observations (Yang et al. 2019). The enhanced subtropical ocean warming, associated with strong upward oceanic heat flux, reduces/increases the 
MTG at equator/polar flanks of the climatological maximum MTG zone around the $20^{\circ}-40^{\circ}$ latitude. This promotes a poleward shift of the mid-latitude MTG and the associated baroclinic instability within the troposphere (Fig. 4a).

Apart from the changes in temperature and heat flux, under increasing $\mathrm{CO}_{2}$ forcing, the atmospheric and oceanic circulation experiences a gradually poleward shift of $2.64^{\circ} \pm$ $0.65^{\circ}$ and $2.57^{\circ} \pm 0.55^{\circ}$, respectively (Figs. 3,4 ). Such shift is manifested in a systematic poleward migration of the patterns of zonal winds (U10), storm track (EKE), precipitation minus evaporation (P-E), SLP and SSH (red lines in Fig. 4). These simulated shifts resemble the systematic shift in the atmospheric and oceanic circulation as illustrated by various observations and climate simulations (Fu et al. 2006; Chen et al. 2008; Archer and Caldeira 2008; Scheff and Frierson 2012; Yang et al. 2020a).

\subsection{Dominant role of SST in driving the shift in atmospheric circulation}

Compared to the $\mathrm{C} 0$ control simulation, the atmospheric circulation shift in the global warming experiment $(\mathrm{C} 1)$ could be driven by two factors, i.e., rising $\mathrm{CO}_{2}$ concentration and changing SST. In the fully coupled system, the evolutions of these two factors occur synchronously. Therefore, it is difficult to discern which factor is more important in directly driving the displacement of the atmospheric circulation. To separate these two factors, we design two experiments here, i.e., C1T0 and C0T1 (see Sect. 2.1 and Fig. 5).

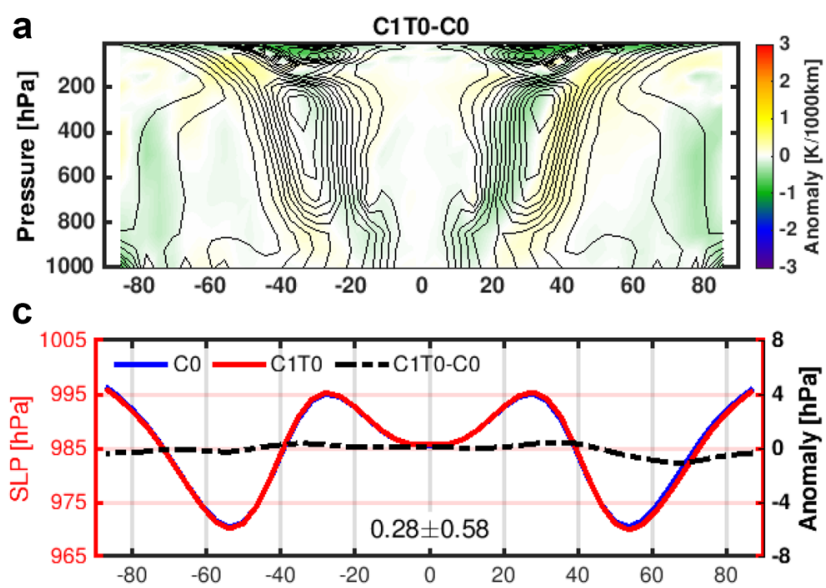

Fig. 5 Similar to Fig. 4, but for comparison between C1T0 (left column, i.e., a and c), C0T1 (right column, i.e., b and d) experiments and the $\mathrm{C} 0$ control experiment. a, b Meridional temperature gradient (MTG) anomaly (shading). The contour lines provide the climatological pattern of the MTG in the C0 experiment. c, d Zonal mean SLP. The blue lines show the value of the control experiment $(\mathrm{C} 0)$, the red lines show the values from the $\mathrm{C} 1 \mathrm{~T} 0$ and $\mathrm{C} 0 \mathrm{~T} 1$ experiments, the
In the $\mathrm{C} 1 \mathrm{~T} 0$ experiment, the strong increase in $\mathrm{CO}_{2}$ induces a $7.6 \mathrm{~W} / \mathrm{m}^{2}$ globally averaged radiation imbalance at the top of the atmosphere (not shown), with strongest longwave radiation anomaly found around $18^{\circ} \mathrm{N} / \mathrm{S}$ owing to the background high outgoing longwave radiation as a result of relatively low coverage of cloud and water vapor (Fig. 6). This spatially ununiform radiation imbalance produces more heating around the subtropical latitudes, thus produces a dipole MTG anomaly within the troposphere, and forces a minor poleward shift of the mid-latitude MTGs (Fig. 5a). Under solely $\mathrm{CO}_{2}$ forcing, $\mathrm{C} 1 \mathrm{~T} 0$ experiment generates a minor poleward shift $\left(0.28^{\circ} \pm 0.58^{\circ}\right)$ of the atmospheric circulation (Fig. 5c). In contrast, without the $\mathrm{CO}_{2}$ forcing, the C0T1 experiment (Fig. 5b, d) obtains a pronounced shift in the MTGs and a strong poleward shift $\left(2.61^{\circ} \pm 0.74^{\circ}\right)$ in the atmospheric circulation. Our results indicate that the shift of the atmospheric circulation is primarily driven by the fundamental change in the thermal condition of the underlying ocean, while the direct radiative effect of increasing $\mathrm{CO}_{2}$ contributes only marginally. Previous studies based on simulations with realistic land-sea configurations also showed a similar finding (Deser and Phillips 2009; Grise and Polvani 2014).

\subsection{Dynamics of shifting atmospheric and oceanic circulation}

Yang et al. (2020b) argued that the warming SST pattern, especially, the subtropical ocean warming plays a critical

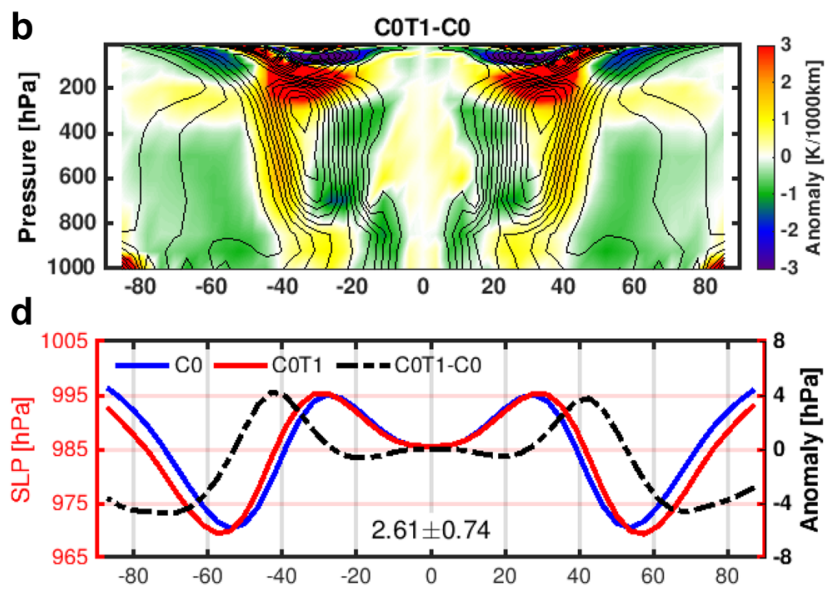

dashed black lines are the differences between the two experiments, i.e., C1T0-C0 and COT1-C0. The poleward shifts of the atmospheric circulation in the C1T0 and C0T1 experiments are $0.28^{\circ}$ and $2.61^{\circ}$ in latitude, respectively. Here, we only show the changes in SLP patterns to indicate the shift in the atmospheric circulation. It should be noted that the other metrics, like the P-E, winds and storm track, have consistent poleward shift as well 


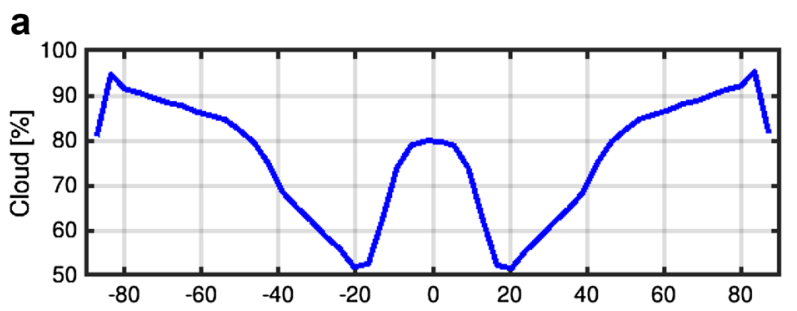

Fig. 6 a Climatological profile of the zonal mean cloud coverage in the $\mathrm{C} 0$ control experiment. It shows relatively less cloud coverage around $18^{\circ} \mathrm{N} / \mathrm{S}$. b Comparison of outgoing longwave radiation between $\mathrm{C} 1 \mathrm{~T} 0$ and $\mathrm{C} 0$ experiment. The blue lines show the value of the control experiment $(\mathrm{C} 0)$, the red lines show the values from the C1T0 experiment, the dashed black line is the difference between the

role in driving the circulation shift. The subtropical ocean warming works to reduce the MTG over the lower latitudes, and increase it over the higher latitudes, thus promoting a poleward shift in the mid-latitude MTG. The coupled nature between the ocean and the atmosphere obfuscates the origin for the enhanced subtropical ocean warming. To disentangle the causal dynamical processes, we further devise three b

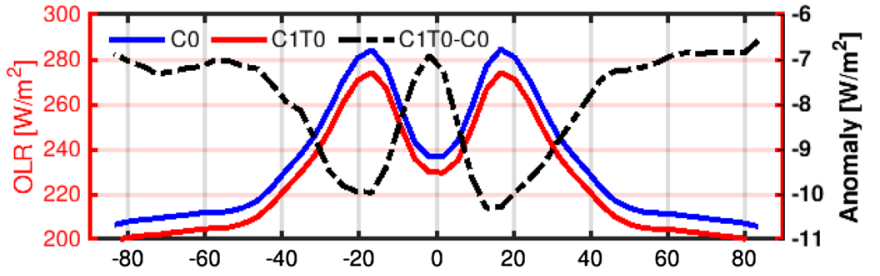

two experiments, i.e., C1T0-C0. The background maximum outgoing longwave radiation locates around $18^{\circ} \mathrm{N} / \mathrm{S}$ due to low coverage of cloud. Under the forcing of increasing $\mathrm{CO}_{2}$, more longwave radiation is absorbed approximately at the same latitudes where there is less cloud

partially coupled aqua-planet simulations: C1W0, COW1, and COW0 (see Sect. 2.1).

In the first experiment (namely the C1W0), we keep increasing the $\mathrm{CO}_{2}$ as the global warming experiment (i.e., $\mathrm{C} 1$ ), but using the hourly wind stress fields from the control experiment (i.e., $\mathrm{C} 0$ ) to force the ocean. Note that the wind forcing taken from the $\mathrm{C} 0$ experiment has
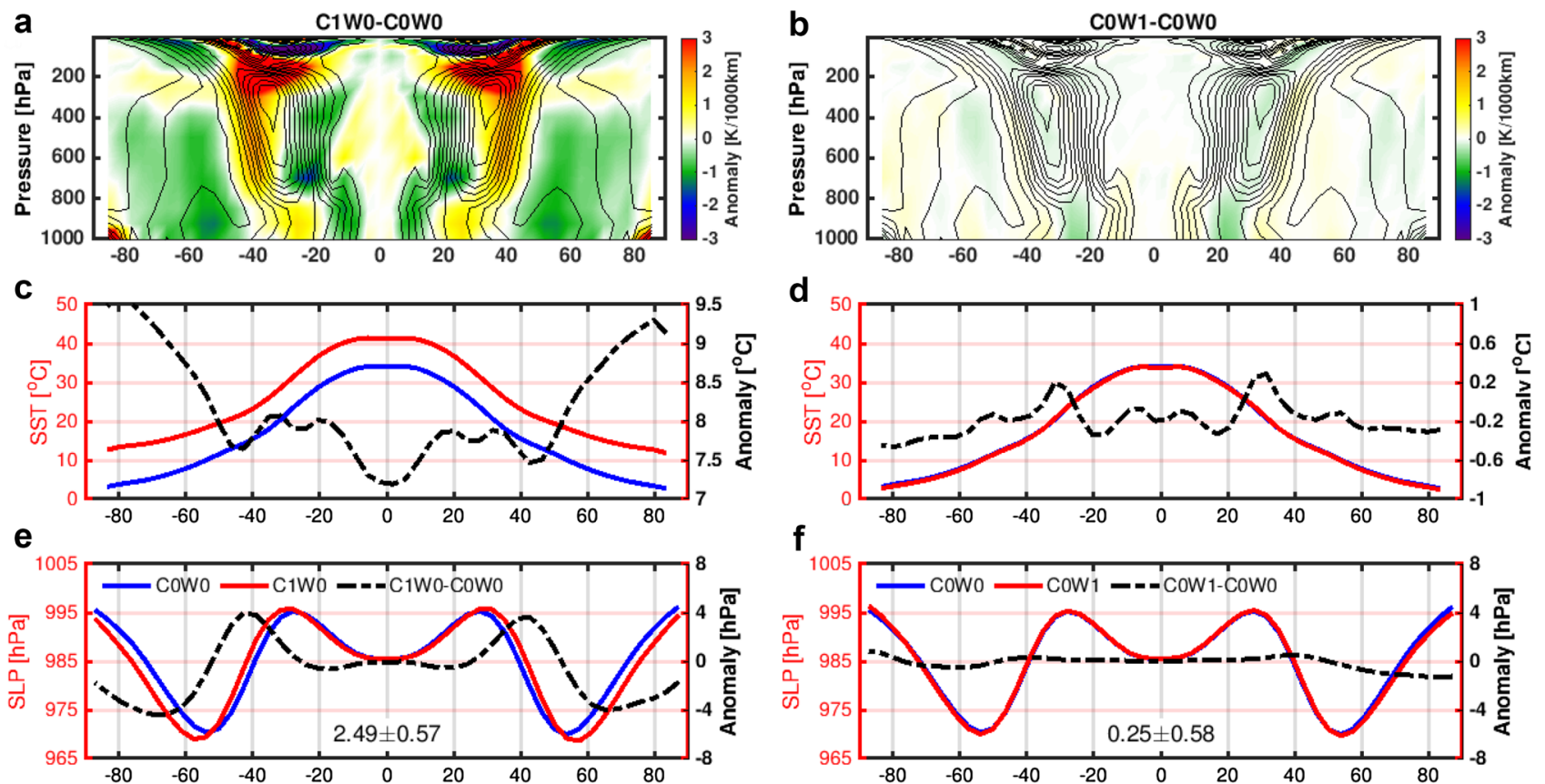

$\mathbf{f}$
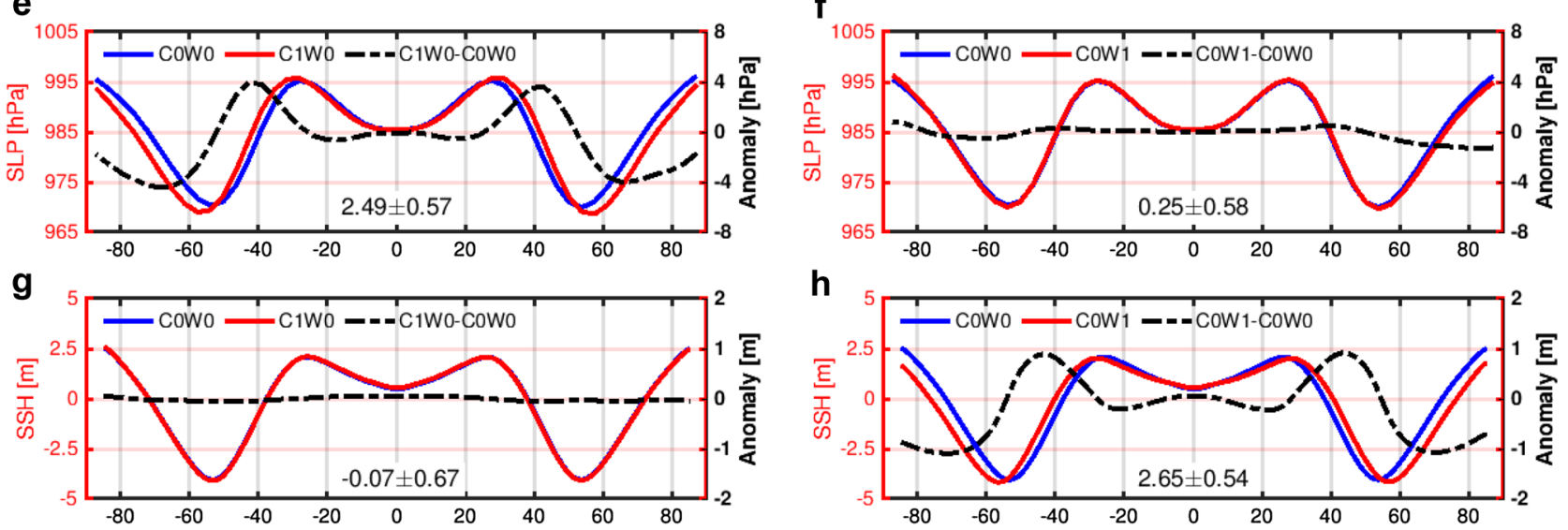

Fig. 7 Similar to Fig. 4, but for results from the partially coupled C1W0 (a, $, \mathbf{e}, \mathbf{e}, \mathbf{g})$ and C0W1 (b, d, f, h) experiments with respect to the C0W0 control experiment 
no signal of poleward shift. As shown in Fig. $7 \mathrm{~g}$, the C1W0 experiment does not show a shift in the SSH pattern $\left(-0.07^{\circ} \pm 0.67^{\circ}\right)$, suggesting that the background ocean circulation has no significant shift once wind forcing is fixed. Without a change in ocean circulation, we still find a pattern of enhanced subtropical ocean warming (Fig. 7c). This implies that the enhanced subtropical ocean warming pattern is independent of the ocean circulation change, but generated by the background ocean circulation.

Driven by the wind stress curl associated with high SLP system, the subtropical ocean is featured by Ekman transport convergence of surface water (Ekman 1905). This convergence does not only converge the surface water, but also collects the anomalous heat contained in the water due to climate warming. Therefore, the C1W0 experiment produces a relatively higher SST over the subtropical latitudes. This result is in agreement with the previous result from a standalone aqua-planet ocean model (Fig. 4d in Yang et al. 2020b). Without a shift in the ocean circulation, the C1W0 experiment reproduces a strong poleward shift $\left(2.49^{\circ} \pm\right.$ $0.57^{\circ}$ ) in the atmospheric circulation (Fig. 7e), with a shift magnitude similar to that in the $\mathrm{C} 1$ experiment (Fig. $4 \mathrm{~g}$ ). The poleward shift of the atmosphere circulation is consistent with the strong poleward displacement of the mid-latitude MTG within the troposphere, as seen in Fig. 7a. This displacement of the MTG is connected to the underlying ocean warming, especially the warming over the subtropical ocean (Fig. 7c).

To understand how the ocean circulation responds to a shift in the atmospheric circulation, we show the results from the C0W1 experiment. In this experiment, we keep the $\mathrm{CO}_{2}$ constant as the $\mathrm{C} 0$ control run, but replace the wind field from the $\mathrm{C} 1$ global warming experiment, which contains the signal of wind shift (Fig. 4c, red line). As shown in Fig. 7h, under forcing of shifting near-surface winds, the ocean circulation exhibits a significant poleward shift $\left(2.65^{\circ} \pm 0.54^{\circ}\right)$. Combining the results from the C0W1 and $\mathrm{C} 1 \mathrm{~W} 0$ experiments, we can conclude that rising $\mathrm{CO}_{2}$ does not directly affect the position of the ocean circulation. The displacement of the ocean circulation is primarily driven by the shift in the atmospheric circulation.

Inspecting the $\mathrm{C} 0 \mathrm{~W} 1$ experiment, we find a minor (around $0.2^{\circ} \mathrm{C}$ ) SST increase/decrease over the polar/equator flanks of subtropical latitudes (Fig. 7d). This is attributed to the shift in the surface ocean circulation, which transports more heat from the lower latitudes towards the higher latitudes. In response to such a SST anomaly, we observe a minor poleward shift $\left(0.25^{\circ} \pm 0.58^{\circ}\right)$ of the atmospheric circulation (Fig. 7f) and a slight change in the mid-latitude MTG within the troposphere (Fig. 7b).

\section{Discussions}

Despite numerous studies during the past decades, there is still no consensus on the main mechanism driving the tropical expansion and the associated poleward shift in the atmospheric and oceanic circulation (Staten et al. 2018; Shaw 2019; Yang et al. 2020b). Even though climate model simulations can reproduce tropical expansion (or poleward shift of the atmospheric circulation) by introducing the forcing of $\mathrm{CO}_{2}$ ( $\mathrm{Lu}$ et al. 2007), ozone (Thompson et al. 2011; Polvani et al. 2011), or aerosols (Allen et al. 2012), observations show that tropical expansion is primarily related to the variations in SST (Allen and Kovilakam 2017; Grise et al. 2019). Yang et al. (2020b) pointed out that the enhanced subtropical ocean warming plays a central role in driving the shift in the atmospheric circulation by modifying the shape of the MTG.

Following Yang et al. (2020b), in the present study we use simplified aqua-planet model simulations to demonstrate that, the direct radiative effect of $\mathrm{CO}_{2}$ is not a potent driver for the shift in the atmosphere circulation. Previously, Staten et al. (2012) also drew a similar conclusion by using a more comprehensive atmosphere model. We find that it is the indirect effect of the $\mathrm{CO}_{2}$ forcing that generates the atmospheric circulation shift through ocean warming, especially that in the subtropics.

The fundamental driver of the atmospheric circulation is the equator-to-pole temperature gradient. Throughout our aqua-planet experiments, we find that the magnitude of the atmospheric circulation shift is closely related to the amplitude of the meridional shift of the mid-latitude MTG within the troposphere. From the perspective of climatology, the maximum MTG with strong frontal activity is found at the subtropical to mid-latitude regions (Fig. 4a, e). On seasonal time scale, the MTGs is more poleward/equatorward located during boreal summer/winter, driving the seasonal displacement of atmospheric and oceanic circulation for more than a thousand kilometers. Therefore, the shape of the equatorto-pole temperature gradients largely controls the position of atmospheric circulation.

Under the $\mathrm{CO}_{2}$ forcing, we observe an enhanced subtropical ocean warming in our aqua-planet simulation (Fig. 1b). This enhanced subtropical ocean warming relies on the background ocean circulation, which transports adjacent anomalous ocean heat toward the subtropical regions. It reduces/increases the MTG over the equator/polar flank of subtropical ocean, therefore drives a shift in the position of the mid-latitude MTG and contributes to the shift of the atmospheric circulation (Fig. 4). The shift in the atmospheric circulation, in turn, forces a shift in the oceanic circulation, helping to further alter the ocean temperature. As a consequence, in a fully coupled system, the enhanced subtropical 
ocean warming is not centred over the subtropical region, but slightly further shifted toward the polar flank of the mean subtropical gyres (Fig. 1). Our aqua-planet simulations well capture the pattern of enhanced subtropical ocean warming, resembling that seen in the observations.

Previously, the dynamics of tropical expansion has also been investigated using aqua-planet models, often under prescribed SST forcing (Williams and Bryan 2006; Frierson et al. 2007; Brayshaw et al. 2008; Chen et al. 2010, 2013; Shaw and Tan 2018). We suggest that the ocean dynamics are important for capturing the full mechanisms, especially, the enhanced subtropical ocean warming generated by mean ocean circulation. An enhanced subtropical ocean warming is an efficient way to drive the shift in the mid-latitude MTG, hence, the shift in the atmospheric circulation. Previously, by manipulating greenhouse warming at different latitudes, Shaw and Tan (2018) found that introducing $\mathrm{CO}_{2}$ around the subtropical regions produces the strongest shift in the atmospheric circulation, likely because the $\mathrm{CO}_{2}$ induces a warming over the subtropical region and thus a poleward shift in the mid-latitude MTG. For the same reason, model simulations forced by increasing black carbon aerosols and ozone (which have similar heating effect as greenhouse gases) over the mid-latitudes also produce a poleward shift in the atmospheric circulation (Allen et al. 2012; Kovilakam and Mahajan 2015). Interestingly, when the shift of atmospheric circulation (or tropical expansion) first drew attention from the scientific community, it was based on the evidence of an enhanced warming over the subtropical troposphere (Fu et al. 2006). This enhanced warming may not only be a manifestation of expanding tropics, but probably also be a key mechanism for the tropical expansion. Our study suggests that the enhanced subtropical warming is not due to atmosphere circulation changes, but has an oceanic origin, which relies on the background oceanic circulation.

The observed enhanced subtropical ocean warming pattern (Fig. 1a) had previously been interpreted as a feature of negative phase of Pacific Decadal Oscillation (Allen and Kovilakam 2017; Grise et al. 2019). However, Yang et al. (2020b) noticed that this subtropical warming pattern exists also during periods of positive phase of Pacific Decadal Oscillation, and across all ocean basins. Our aqua-planet simulations, in the absence of fluctuations of Pacific Decadal Oscillation, show that under global warming, background Ekman transport convergence of subtropical surface water contributes to generating an enhanced subtropical ocean warming, similar to that seen in the observations. This hints that, apart from the swing of Pacific Decadal Oscillation, the observed enhanced subtropical ocean warming may partly arise from climate change. As the phase of Pacific Decadal Oscillation can flip sign, the part of the subtropical warming owing to the increasing greenhouse gases forcing is expected to keep growing in the coming decades, causing a long-standing poleward shift in the atmospheric and oceanic circulation.

Held (2000) proposed that the edge of the Hadley cell is determined by the latitude that angular-momentum conservation continues polewards until the resulting vertical shears become baroclinically unstable. The baroclinic instability is the fundamental mechanism generating the eddies that dominate the weather in the mid-latitudes. Expanding Hadley cell (or poleward shift of the atmosphere circulation) ties to a systematic poleward shift of the mid-latitude eddy activity (Fig. 4e), which relates to a poleward shift of the baroclinicity (Yin 2005; Mbengue and Schneider 2018; Simmonds and Li 2021). Rudeva et al. (2019) found that changes in mid-latitude frontal activity (strong temperature gradients) lead those in the edge of the Hadley cell by approximately one day.

Baroclinicity itself is affected by both the vertical temperature gradient (i.e., the static stability) and the horizontal temperature gradient. Many previous investigations ( $\mathrm{Lu}$ et al. 2007, 2009; Vallis et al. 2015; Son et al. 2018; Chemke and Polvani 2019) suggest that increasing static stability associated with mean warming contributes to the expanding Hadley cell. However, sensitivity simulations show that the atmospheric warming over the deep tropics (Sun et al. 2013; Tandon et al. 2013; Watt-Meyer and Frierson 2019; Zhou et al. 2019) and polar region (Wu and Smith 2016; Butler et al. 2010) both contributes to an equatorward contraction of atmospheric circulation. Compared to other latitudes, the warming around the subtropical regions is found to contribute the most to the tropical expansion (Tandon et al. 2013; Shaw and Tan 2018). We propose that by reshaping the horizontal temperature gradient, the enhanced subtropical ocean warming acts as an efficient mechanism for shifting of the mid-latitude baroclinicity and the atmospheric circulation. However, as we are unable to disentangle the effects of static stability from the horizontal temperature gradient, the relative importance of static stability in driving the circulation displacement still needs to be quantified in the future.

Systematic poleward shift of the circulation has broad manifestations, affecting the atmosphere, ocean, hydrosphere and biosphere (Scheff and Frierson 2012; Hu et al. 2015; Heffernan 2016; Yang et al. 2020a; Franco et al. 2020). Therefore, the displacement of the large-scale circulation system is plausible to be identified by some regional climate changes. One particular case is the changes of the oceanic western boundary currents, where the climate change signal is amplified by the effect of 'western intensification' (Stommel 1948). Modern long-term observations of the Gulf Stream (Frankignoul et al. 2001) and the Eastern Austrian Current (Ridgway 2007), show that these currents have undergone a considerable poleward shift for more than 
half century (Wu et al. 2012; Yang et al. 2016b). This piece of evidence may imply that the circulation system has perhaps already shifted. Satellite observations may not capture the full magnitude of the circulation shift due to their short temporal coverages. Paleo-climate proxy records reveal that the Kuroshio Current (Gray et al. 2020) and the Agulhas Current (Bard and Rickaby 2009) were a few hundred kilometers closer to the equator during the ice age, hinting that the ongoing circulation movement is possible to develop further in the long-term future. Considering that the atmosphere and ocean circulation largely determines the regional climate and the spatial distribution of natural ecosystems, the ongoing shifting circulation may reshape the climate and ecological zones with profound natural and societal impacts.

\section{Conclusions}

The dynamics of poleward shift of the atmospheric and oceanic circulation is explored using several sets of aquaplanet model simulations. We find that the direct $\mathrm{CO}_{2}$ forcing plays a minor role in contributing the atmospheric circulation shift. In contrast, the induced ocean warming plays a dominant role in driving the atmospheric circulation displacement. Under the $\mathrm{CO}_{2}$ induced radiative forcing, the background ocean Ekman transport convergence near the subtropical region generates an enhanced subtropical ocean surface warming. This enhanced subtropical warming, causes poleward displacement in the mid-latitude temperature gradient, forcing a corresponding shift in the atmospheric circulation (Fig. 8). The shift in the atmospheric circulation, manifested with a poleward shift in the near-surface winds, in turn, drives a poleward shift in the ocean circulation. The changes in ocean circulation produce slightly warmer/cooler SST anomalies at the polar/equator flanks of the subtropical ocean, promoting a further minor shift in the atmospheric circulation. Overall, the changes in the ocean thermal condition drive the changes in the atmospheric circulation, which in turn reshape the wind-driven ocean circulation. On the other hand, the feedback from the wind-driven ocean circulation change to the atmosphere circulation is at best secondary.

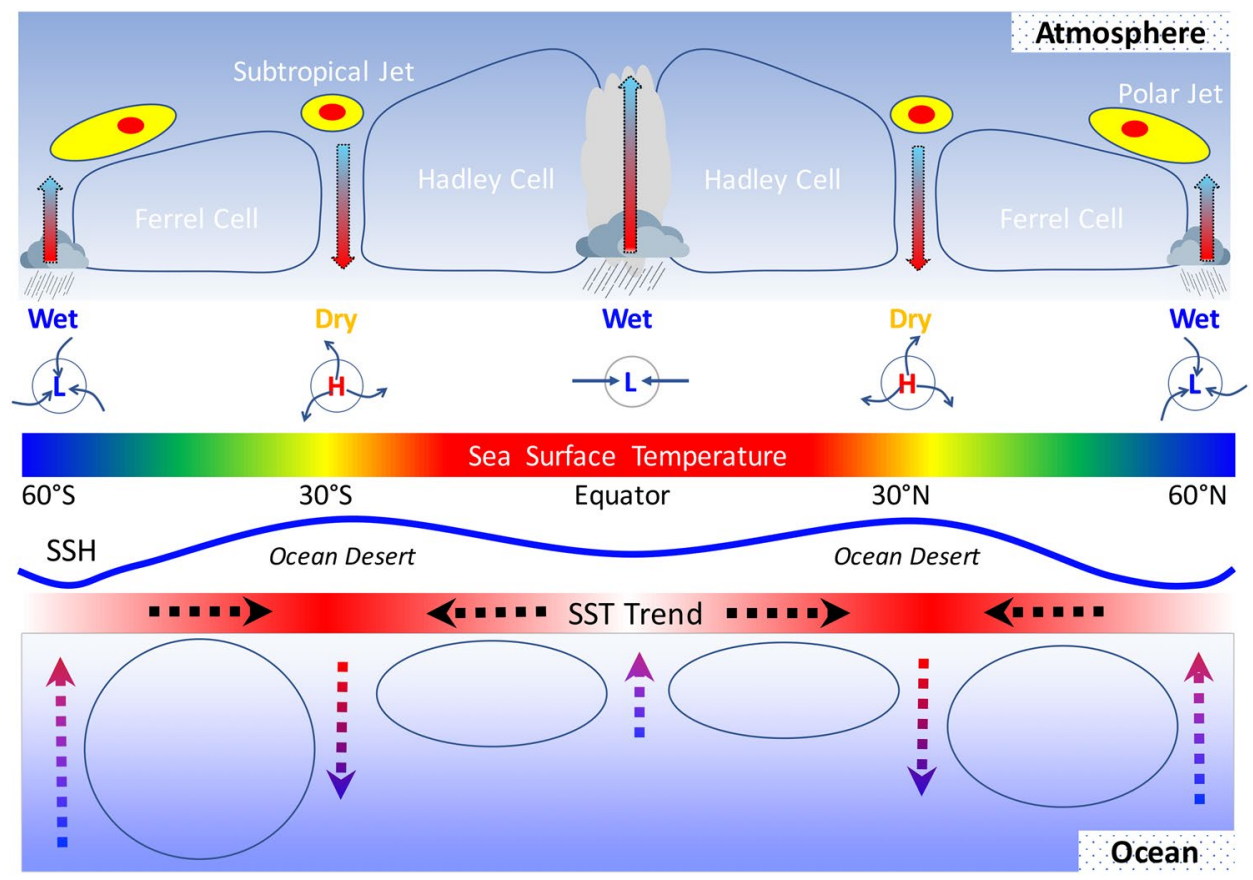

Fig. 8 Schematic diagram showing how background ocean circulation promotes an enhanced subtropical ocean warming and drives the shift in the atmospheric and oceanic circulation. The arrows illustrate the significant features of atmospheric (solid) and oceanic (dashed) circulation. From a climatological perspective, the maximum meridional temperature gradients (MTGs) locate at the subtropical to midlatitude regions. The position of MTGs determines the position of the atmosphere circulation, thus the position of the wind-driven ocean circulation. Under the forcing of increasing greenhouse gases, background Ekman transport convergence of surface water favours an enhanced subtropical ocean warming. This enhanced warming expands the low latitude warm water zones, pushes the mid-latitude MTGs towards higher latitudes, and thus forcing a poleward shift in the atmospheric circulation. The shift in the atmospheric circulation, manifested with a corresponding shift in the near-surface wind then forces a shift in the oceanic circulation. Systematic shift of atmospheric and oceanic circulation redistributes the natural resources, such as water, vegetation, marine primary productivity, hence has broad implications for our societies 
Supplementary Information The online version contains supplementary material available at https://doi.org/10.1007/s00382-021-06112-0.

Acknowledgements We thank two anonymous reviewers for providing constructive comments. We acknowledge Dirk Barbi for providing the advice on the Message Passing Interface (MPI) coding for the partially coupled aqua-planet model. We would also like to thank the AWI computer centre for supporting the simulation of our study, especially our colleagues Malte Thoma and Natalja Rakowsky. This work is supported by the AWI INSPIRES program of "Changing Earth-Sustaining our Future", the German Helmholtz Climate Initiative REKLIM (Regional Climate Change) and the open fund of State Key Laboratory of Loess and Quaternary Geology, Institute of Earth Environment, CAS (SKLLQG1920). JL is supported by the Office of Science of the U.S. Department of Energy (DOE) as part of the Regional and Global Climate Modeling (RGCM) program. The observational sea surface height data were produced by Ssalto/Duacs and distributed by Aviso, with support from Cnes http://www.aviso.altimetry.fr/duacs/. The observational sea surface temperature data (NOAA_OI_SST_V2) is provided by the NOAA/OAR/ESRL PSD, Boulder, Colorado, USA, from their website at http://www.esrl.noaa.gov/psd/.

Funding Open Access funding enabled and organized by Projekt DEAL.

\section{Declarations}

Conflict of interest The authors declare that they have no conflict of interest.

Open Access This article is licensed under a Creative Commons Attribution 4.0 International License, which permits use, sharing, adaptation, distribution and reproduction in any medium or format, as long as you give appropriate credit to the original author(s) and the source, provide a link to the Creative Commons licence, and indicate if changes were made. The images or other third party material in this article are included in the article's Creative Commons licence, unless indicated otherwise in a credit line to the material. If material is not included in the article's Creative Commons licence and your intended use is not permitted by statutory regulation or exceeds the permitted use, you will need to obtain permission directly from the copyright holder. To view a copy of this licence, visit http://creativecommons.org/licenses/by/4.0/.

\section{References}

Allen RJ, Kovilakam M (2017) The role of natural climate variability in recent tropical expansion. J Clim 30(16):6329-6350

Allen RJ, Sherwood SC, Norris JR, Zender CS (2012) Recent Northern Hemisphere tropical expansion primarily driven by black carbon and tropospheric ozone. Nature 485(7398):350

Archer CL, Caldeira K (2008) Historical trends in the jet streams. Geophys Res Lett 35(8):L08,803. https://doi.org/10.1029/2008GL033614

Bard E, Rickaby RE (2009) Migration of the subtropical front as a modulator of glacial climate. Nature 460(7253):380-383

Brayshaw D, Hoskins B, Blackburn M (2008) The storm-track response to idealized SST perturbations in an aquaplanet GCM. J Atmos Sci 65(9):2842-2860

Butler AH, Thompson DW, Heikes R (2010) The steady-state atmospheric circulation response to climate change-like thermal forcings in a simple general circulation model. J Clim 23(13):3474-3496
Carton JA, Giese BS (2008) A reanalysis of ocean climate using Simple Ocean Data Assimilation (SODA). Mon Weather Rev 136(8):2999-3017

Chemke R, Polvani LM (2019) Exploiting the abrupt $4 \times \mathrm{CO}_{2}$ scenario to elucidate tropical expansion mechanisms. J Clim 32(3):859-875

Chen G, Lu J, Frierson DM (2008) Phase speed spectra and the latitude of surface westerlies: interannual variability and global warming trend. J Clim 21(22):5942-5959

Chen G, Plumb RA, Lu J (2010) Sensitivities of zonal mean atmospheric circulation to SST warming in an aqua-planet model. Geophys Res Lett 37(12):L12,701. https://doi.org/10.1029/2010GL043473

Chen G, Lu J, Sun L (2013) Delineating the eddy-zonal flow interaction in the atmospheric circulation response to climate forcing: uniform SST warming in an idealized aquaplanet model. J Atmos Sci 70(7):2214-2233

Deser C, Phillips AS (2009) Atmospheric circulation trends, 19502000: the relative roles of sea surface temperature forcing and direct atmospheric radiative forcing. J Clim 22(2):396-413

Ekman VW (1905) On the influence of the earth's rotation on oceancurrents. Arkiv for Matematik Astronomi och Fysik 2:1-52

Franco BC, Defeo O, Piola AR, Barreiro M, Yang H, Ortega L, Gianelli I, Castello JP, Vera C, Buratti C et al (2020) Climate change impacts on the atmospheric circulation, ocean, and fisheries in the southwest South Atlantic Ocean: a review. Clim Change 162:2359-2377. https://doi.org/10.1007/s10584-020-02783-6

Frankignoul C, de Coëtlogon G, Joyce TM, Dong S (2001) Gulf stream variability and ocean-atmosphere interactions. J Phys Oceanogr 31(12):3516-3529

Frierson DM, Lu J, Chen G (2007) Width of the Hadley cell in simple and comprehensive general circulation models. Geophys Res Lett 34(18):L18,804. https://doi.org/10.1029/2007GL031115

Fu Q, Johanson CM, Wallace JM, Reichler T (2006) Enhanced midlatitude tropospheric warming in satellite measurements. Science 312(5777): 1179

Gray WR, Wills RC, Rae JW, Burke A, Ivanovic RF, Roberts WH, Ferreira D, Valdes PJ (2020) Wind-driven evolution of the North Pacific subpolar gyre over the last deglaciation. Geophys Res Lett 47(6):e2019GL086,328

Grise KM, Polvani LM (2014) The response of midlatitude jets to increased $\mathrm{CO}_{2}$ : distinguishing the roles of sea surface temperature and direct radiative forcing. Geophys Res Lett 41(19):6863-6871

Grise KM, Davis SM, Simpson IR, Waugh DW, Fu Q, Allen RJ, Rosenlof KH, Ummenhofer CC, Karnauskas KB, Maycock AC et al (2019) Recent tropical expansion: natural variability or forced response? J Clim 32(5):1551-1571

Heffernan O (2016) The mystery of the expanding tropics. Nat News 530(7588):20

Held I (2000) The general circulation of the atmosphere, 2000 program of study in geophysical fluid dynamics. Woods Hole Oceanogr Inst Tech Rep WHOI-2001 3

Hersbach H, Bell B, Berrisford P, Hirahara S, Horányi A, MuñozSabater J, Nicolas J, Peubey C, Radu R, Schepers D et al (2020) The ERA5 global reanalysis. Q J R Meteorol Soc 146(730):1999-2049

$\mathrm{Hu}$ Y, Fu Q (2007) Observed poleward expansion of the Hadley circulation since 1979. Atmos Chem Phys 7(19):5229-5236

Hu D, Wu L, Cai W, Gupta AS, Ganachaud A, Qiu B, Gordon AL, Lin X, Chen Z, Hu S et al (2015) Pacific western boundary currents and their roles in climate. Nature 522(7556):299-308

Kossin JP, Emanuel KA, Vecchi GA (2014) The poleward migration of the location of tropical cyclone maximum intensity. Nature 509(7500):349

Kovilakam M, Mahajan S (2015) Black carbon aerosol-induced Northern Hemisphere tropical expansion. Geophys Res Lett 42(12):4964-4972 
Lin X, Zhai X, Wang Z, Munday DR (2020) Southern Ocean wind stress in CMIP5 models: role of wind fluctuations. J Clim 33(4):1209-1226

Lohmann G (2020) Temperatures from energy balance models: the effective heat capacity matters. Earth Syst Dyn 11(4):1195-1208. https://doi.org/10.5194/esd-11-1195-2020

Lu J, Vecchi GA, Reichler T (2007) Expansion of the Hadley cell under global warming. Geophys Res Lett 34(6):L06,805. https://doi.org/ 10.1029/2006GL028443

Lu J, Deser C, Reichler T (2009) Cause of the widening of the tropical belt since 1958. Geophys Res Lett 36(3):L03,803. https://doi.org/ 10.1029/2008GL036076

Ma W, Chen G, Guan B (2020) Poleward shift of atmospheric rivers in the Southern Hemisphere in recent decades. Geophys Res Lett 47(21):e2020GL089,934. https://doi.org/10.1029/2020GL089934

Marshall GJ (2003) Trends in the Southern Annular Mode from observations and reanalyses. J Clim 16(24):4134-4143

Mbengue C, Schneider T (2018) Linking Hadley circulation and storm tracks in a conceptual model of the atmospheric energy balance. $\mathrm{J}$ Atmos Sci 75(3):841-856

Norris JR, Allen RJ, Evan AT, Zelinka MD, ODell CW, Klein SA (2016) Evidence for climate change in the satellite cloud record. Nature 536(7614):72-75

Polvani LM, Waugh DW, Correa GJ, Son SW (2011) Stratospheric ozone depletion: the main driver of twentieth-century atmospheric circulation changes in the Southern Hemisphere. J Clim 24(3):795-812

Rackow T, Goessling HF, Jung T, Sidorenko D, Semmler T, Barbi D, Handorf D (2018) Towards multi-resolution global climate modeling with ECHAM6-FESOM. Part II: climate variability. Clim Dyn 50(7):2369-2394

Ridgway KR (2007) Long-term trend and decadal variability of the southward penetration of the East Australian Current. Geophys Res Lett 34(13):L13,613. https://doi.org/10.1029/2007GL030393

Rudeva I, Simmonds I (2015) Variability and trends of global atmospheric frontal activity and links with large-scale modes of variability. J Clim 28(8):3311-3330

Rudeva I, Simmonds I, Crock D, Boschat G (2019) Midlatitude fronts and variability in the Southern Hemisphere tropical width. J Clim 32(23):8243-8260

Scheff J, Frierson D (2012) Twenty-first-century multimodel subtropical precipitation declines are mostly midlatitude shifts. J Clim 25(12):4330-4347

Screen JA, Bracegirdle TJ, Simmonds I (2018) Polar climate change as manifest in atmospheric circulation. Curr Clim Change Rep 4(4):383-395

Seidel DJ, Fu Q, Randel WJ, Reichler TJ (2008) Widening of the tropical belt in a changing climate. Nat Geosci 1(1):21-24

Shaw TA (2019) Mechanisms of future predicted changes in the zonal mean mid-latitude circulation. Curr Clim Change Rep 5(4):345-357

Shaw TA, Tan Z (2018) Testing latitudinally dependent explanations of the circulation response to increased $\mathrm{CO}_{2}$ using aquaplanet models. Geophys Res Lett 45(18):9861-9869

Sidorenko D, Rackow T, Jung T, Semmler T, Barbi D, Danilov S, Dethloff K, Dorn W, Fieg K, Gößling HF et al (2015) Towards multi-resolution global climate modeling with ECHAM6FESOM. Part I: model formulation and mean climate. Clim Dyn 44(3-4):757-780

Sidorenko D, Goessling H, Koldunov N, Scholz P, Danilov S, Barbi D, Cabos W, Gurses O, Harig S, Hinrichs C et al (2019) Evaluation of FESOM2.0 coupled to ECHAM6.3: preindustrial and HighResMIP simulations. J Adv Model Earth Syst 11(11):3794-3815

Simmonds I, Li M (2021) Trends and variability in polar sea ice, global atmospheric circulations, and baroclinicity. Ann NY Acad Sci. https://doi.org/10.1111/nyas.14673
Smith RS, Dubois C, Marotzke J (2006) Global climate and ocean circulation on an aquaplanet ocean-atmosphere general circulation model. J Clim 19(18):4719-4737

Son SW, Kim SY, Min SK (2018) Widening of the Hadley cell from last glacial maximum to future climate. J Clim 31(1):267-281

Staten PW, Rutz JJ, Reichler T, Lu J (2012) Breaking down the tropospheric circulation response by forcing. Clim Dyn 39(9-10):2361-2375

Staten PW, Lu J, Grise KM, Davis SM, Birner T (2018) Re-examining tropical expansion. Nat Clim Change 8:768-775

Stevens B, Giorgetta M, Esch M, Mauritsen T, Crueger T, Rast S, Salzmann M, Schmidt H, Bader J, Block K et al (2013) Atmospheric component of the MPI-M Earth System Model: ECHAM6. J Adv Model Earth Syst 5(2):146-172

Stommel H (1948) The westward intensification of wind-driven ocean currents. EOS Trans Am Geophys Union 29(2):202-206

Sun L, Chen G, Lu J (2013) Sensitivities and mechanisms of the zonal mean atmospheric circulation response to tropical warming. J Atmos Sci 70(8):2487-2504

Tandon NF, Gerber EP, Sobel AH, Polvani LM (2013) Understanding Hadley cell expansion versus contraction: insights from simplified models and implications for recent observations. J Clim 26(12):4304-4321

Thompson DW, Wallace JM, Hegerl GC (2000) Annular modes in the extratropical circulation. Part II: trends. J Clim 13(5):1018-1036

Thompson DW, Solomon S, Kushner PJ, England MH, Grise KM, Karoly DJ (2011) Signatures of the Antarctic ozone hole in Southern Hemisphere surface climate change. Nat Geosci 4(11):741

Vallis GK, Zurita-Gotor P, Cairns C, Kidston J (2015) Response of the large-scale structure of the atmosphere to global warming. Q J R Meteorol Soc 141(690):1479-1501

Wang Q, Danilov S, Sidorenko D, Timmermann R, Wekerle C, Wang X, Jung T, Schröter J (2014) he Finite Element Sea Ice-Ocean Model (FESOM) v. 1.4: formulation of an ocean general circulation model. Geosci Model Dev 7(2):663-693

Watt-Meyer O, Frierson DM (2019) ITCZ width controls on Hadley cell extent and eddy-driven jet position and their response to warming. J Clim 32(4):1151-1166

Williams GP, Bryan K (2006) Ice age winds: an aquaplanet model. J Clim 19(9):1706-1715

Wu Y, Smith KL (2016) Response of Northern Hemisphere midlatitude circulation to Arctic amplification in a simple atmospheric general circulation model. J Clim 29(6):2041-2058

Wu L, Cai W, Zhang L, Nakamura H, Timmermann A, Joyce T, McPhaden MJ, Alexander M, Qiu B, Visbeck M et al (2012) Enhanced warming over the global subtropical western boundary currents. Nat Clim Change 2(3):161-166

Wu B, Lin X, Yu L (2021) Poleward shift of the Kuroshio extension front and its impact on the north pacific subtropical mode water in the recent decades. J Phys Oceanogr 51(2):457-474

Yang H, Liu J, Lohmann G, Shi X, Hu Y, Chen X (2016a) Oceanatmosphere dynamics changes associated with prominent ocean surface turbulent heat fluxes trends during 1958-2013. Ocean Dyn 66(3):353-365

Yang H, Lohmann G, Wei W, Dima M, Ionita M, Liu J (2016b) Intensification and poleward shift of subtropical western boundary currents in a warming climate. J Geophys Res Oceans 121(7):4928-4945

Yang H, Lohmann G, Shi X, Li C (2019) Enhanced mid-latitude meridional heat imbalance induced by the ocean. Atmosphere 10(12):746

Yang H, Lohmann G, Krebs-Kanzow U, Ionita M, Shi X, Sidorenko D, Gong X, Chen X, Gowan EJ (2020a) Poleward shift of the major ocean gyres detected in a warming climate. Geophys Res Lett 47(5):e2019GL085,868 
Yang H, Lohmann G, Lu J, Gowan EJ, Shi X, Liu J, Wang Q (2020b) Tropical expansion driven by poleward advancing midlatitude meridional temperature gradients. J Geophys Res Atmos 125(16):e2020JD033,158

Yin JH (2005) A consistent poleward shift of the storm tracks in simulations of 21 st century climate. Geophys Res Lett 32(18):L18,701. https://doi.org/10.1029/2005GL023684
Zhou W, Xie SP, Yang D (2019) Enhanced equatorial warming causes deep-tropical contraction and subtropical monsoon shift. Nat Clim Change 9(11):834-839

Publisher's Note Springer Nature remains neutral with regard to jurisdictional claims in published maps and institutional affiliations. 